\title{
Comment
}

\section{Reflecting on 'European policymaking on the tobacco advertising ban: the importance of escape routes'}

\author{
MARTIN MCKEE* \\ Professor of European Public Health, London School of Hygiene and Tropical Medicine, London
}

For many centuries, authorities have sought to balance the interests of commerce and those of public health. In the 14th century, when faced with the threat of plague, the Venetian authorities required ships entering the port of Ragusa, now Dubrovnik, to wait for 30 days on nearby islands. In time this delay was extended to 40 days, or quaranta giorni, giving rise to the term quarantine (Gensini et al., 2004). The 19th century saw a new dimension to the relationship between trade and health when the United Kingdom went to war with China to assert its right to export opium in the face of opposition from the Chinese authorities concerned about the impact on the health (and productivity) of its population (McKee, 2009). Such disputes were often less violent in the 20th century but, as late as the 1980s, the United States government threatened trade sanctions against Thailand to force it to open its domestic market to American corporations, along with their sophisticated marketing techniques and enormous budgets (Callard et al., 2001). Today there are serious concerns that international trade agreements are being used to undermine national measures to protect health (Jarman, 2014), especially given evidence of how trade liberalisation in recent decades has driven increases in use of harmful substances in low and middle income countries (Stuckler et al., 2012).

These tensions have been played out on several occasions within the European Union, where a single market based on free movement of goods, services, capital and people poses both threats and opportunities to public health (McKee et al., 2002). Some of the most contested issues have related to tobacco, a substance that, although legally produced and sold, will kill $50 \%$ of those who use it as intended (World Health Organization, 2009). How should authorities balance the rights of those who manufacture such a product with the protection of those members of the public who use it or are exposed to its toxic effects?

In a paper published in this journal in 2011, Adamini et al. embarked on a journey through the labyrinthine processes that led, ultimately, to a ban on

\footnotetext{
*Correspondence to: Martin McKee, Professor of European Public Health, London School of Hygiene and Tropical Medicine, 15-17 Tavistock Place, London, WC1H 9SH, UK. Email: martin.mckee@lshtm.ac.uk
} 
cross-border tobacco advertising (Adamini et al., 2011). They showed how the measure was delayed by governments that simply regurgitated the tobacco industry's arguments, with Germany even submitting a proposal that, it later transpired, had been drafted by the tobacco industry. They highlighted the importance of domestic policies, with the election of a Labour government in the United Kingdom in 1997 changing the dynamic in the Council of Ministers. They exposed the behind the scenes deal making, with Germany seemingly trading support for structural funds for a Spanish abstention that risked blocking agreement. And they reminded us that national governments are not monolithic and that, when health is being discussed, it is often ministries of finance, trade and agriculture that prevail over health. However, they also show how politically astute actors, in governments, civil society and the European Parliament, can ensure the passage of measures that protect the health of the European population. Crucially, they showed how the European Court of Justice, while upholding the law as agreed by the Member States, and thus rejecting the initial Directive, placed a high priority on public health by offering very clear guidance on how to draft a revised Directive that would be compliant with the Treaty.

Beyond the debate about the relative priority to be given to trade and public health, the choice of the Tobacco Advertising Directive as a vehicle to illustrate the legislative process in the European Union was a good one. It illustrated well the tensions inherent in deciding which measures should be the responsibility of Member States and which require concerted European action. Although the principles involved, subsidiarity and proportionality, are clearly described in legislation and their meanings have been explored in an extensive body of case law, their interpretation can still be debated (Tridimas, 2006). Adamini et al. also illustrate how the sheer complexity of the legislative process offers many opportunities to delay or derail legislation, even when it has widespread support. Yet inevitably, there were some issues that could have been explored further had space permitted.

While the eventual passage of the Tobacco Advertising Directive came about when the United Kingdom and the the Netherlands moved to support it, some governments have been consistently opposed to any measure that would harm the interests of the tobacco industry. The most prominent have been Germany and Austria. As Adamini et al. note, it was Germany that challenged the legality of the initial version of the Tobacco Advertising Directive, both in its initial form and following revision, even though that revision drew on clear advice from the European Court of Justice about what it would consider consistent with the Treaty. The reasons for this opposition are only partially understood.

One frequently cited argument is that the views of both countries were shaped by their experiences during the Second World War, when certain Nazis, including Hitler, were strongly opposed to smoking. This argument is ruthlessly exploited by pro-tobacco groups, using terms such as Nico-Nazi to attack public health professionals. It is certainly true that some within the Nazi Party were anti-tobacco, but this was far from universal and several prominent 
individuals, such as Goering and Goebbels, smoked publicly. More detailed examination of archival material in both countries reveal that the link between Nazism and anti-smoking measures is greatly exaggerated (Bachinger and McKee, 2007; Bachinger et al., 2008), leading some to coin the term reductio ad Hitlerium (Proctor, 2008), drawing upon the more common critique of a fallacious argument, reductio ad absurdum. Moreover, this argument cannot explain the opposition, at various times, by countries such as Denmark, the Netherlands and the United Kingdom.

There is, however, some evidence that suggests a more prosaic explanation for why certain countries, at particular times opposed measures to protect their populations from tobacco. Quite simply, some key players in the domestic policy arena in certain countries are being paid by the tobacco industry. In some cases this is entirely open (Neuman et al., 2002). Thus, in the United Kingdom a former health minister has been a non-executive director of British American Tobacco. After being removed from office, British Prime Minister Margaret Thatcher accepted a contract from Philip Morris for \$500,000 per year to advise them on entry to emerging markets in Eastern Europe. Other payments are less transparent. Some have been revealed in studies of internal industry documents released under court order in the United States. Thus, the tobacco industry created a large, complex network of organisations to support scientists that would promote its positions on key issues or, where appropriate, sow confusion with the goal of delaying or preventing legislation (Gruning et al., 2006).

Unfortunately, such studies are still relatively few in number. The nexus of relationships between the tobacco industry, politicians, civil servants and advisors is still very opaque in many countries. Moreover, public health policies involve products other than tobacco, in particular, alcohol and energy dense food and soft drinks. The limited amount of evidence available suggests that many of the same tactics are used by those manufacturing all of these products, often drawing on advice from the same public relations companies (McKee, 2006). As the Dirty Politics affair in New Zealand has shown, the financial links between politicians and the tobacco, food and alcohol industries can be extremely complex and intertwined (Hager, 2014). It was shown that a prominent political blogger had been receiving both insider information from government ministers and their advisers about officials and opposition politicians to be attacked and, simultaneously, funding from the tobacco and food industries and those representing them (McKee, 2014).

Adamini et al. note how lobbyists played a role in the Tobacco Advertising Directive but their efforts were concentrated at national level. This was unsurprising as, until then, it was not even certain that the European Union had competence in the field of tobacco control or, if it did, how far it extended. Until 1986, when the Single European Treaty required the European Commission to 'take a high level of health protection as a base for its proposals', health had barely been mentioned except insofar as it related to certain cross-border workers (McKee et al., 2002). However, the new requirement only extended to policies 
'in the field of health, safety, environmental protection and consumer protection'. It was only in 1992, in the Maastricht Treaty, that the European Union was given any formal legal competence in public health. Until then, tobacco industry lobbyists concentrated their efforts where they always had done so, in their domestic markets, building on existing links with individual politicians.

The Tobacco Advertising Directive changed that (Peeters et al., 2015). The industry realised that it would need to develop a presence in Brussels. When the next threat to it emerged, in the form of the Tobacco Products Directive, it was ready with a clear strategy, to amend the text, delay its passage and block those elements it considered most harmful to its interests (Mandal et al., 2009). It had mobilised a large group of lobbyists, with Philip Morris alone employing 160 full time staff in this role (Philip Morris International, 2013). Some lobbyists were former Commission officials and Members of the European Parliament (MEPs) (Corporate Europe Observatory, 2014). The industry also engaged with, and in some cases created, a large number of third party organisations, presenting themselves as the voices of small retailers, magazine publishers and similar, that could claim, however misleadingly, that the proposed Directive would impact adversely on their livelihoods and, thus, their ability to create jobs. Crucially, the industry had worked behind the scenes to ensure that the Commission's approach to impact assessment would prioritise economic issues over health, on the basis that it could frame its arguments in ways that could exploit the process to its benefit (Mandal et al., 2009). In contrast, as Adamini et al. noted, the capacity to advocate for public health had been eroded, in part as a consequence of pressure from some quarters, including pro-tobacco governments, to withdraw European Union support for them. One MEP commented that the Tobacco Products Directive was "the most lobbied dossier in the history of the EU institutions" (Corlett, 2013).

Given the scale of effort expended by the tobacco industry, it is unsurprising that they achieved some success. A recent analysis that tracked changes in the text of the draft Directive as it passed through the legislative process showed how the wording changed, moving progressively away from that employed in submissions by public health organisations towards that used in tobacco industry submissions(Costa et al., 2014). However, the processes by which this happened have yet to be fully elucidated.

Adamini et al. employed an actor-centred institutionalist approach (Scharpf, 1997). As discussed above, this was inevitably incomplete as it focused almost entirely on those actors who are visible, and among them, mostly those activities that they conducted that were visible. Yet, many of the key decisions seem likely to have involved actors that are largely invisible and whose activities take place in private. By recognising this, it is possible to set out a research agenda to understand better how health policy is made. This would explicitly address the issue of corruption and the closely associated phenomenon of organised crime. A few studies have looked at corruption and tobacco policy, mostly in low and middle income countries (Alechnowicz and Chapman, 2004; Titeca et al., 2011) but one has shown that a widely used measure of perceptions of corruption was closely associated with weak 
tobacco control policies in European Union member states (Bogdanovica et al., 2011). As Poland has taken over from Germany as the tobacco industry's main champion in the European Union, there is a need for further research on the reasons why it has done so. Revelations of links between the pharmaceutical industry and Polish authorities are not reassuring (Ozieranski et al., 2012).

Rather fewer studies have looked at the relationship between health and organised crime (Reynolds and McKee, 2010), which is often closely related to corruption. However, the research that has been undertaken demonstrates the importance of this phenomenon in tobacco control, with examples of complicity of senior politicians in some countries in large scale cigarette smuggling (Glenny, 2009). It is unlikely that the same politicians will be diligent in pursuit of tobacco control. In some cases, the tobacco industry seems to view complicity in smuggling and lobbying as different elements of a single strategy (Skafida et al., 2014).

A comprehensive research agenda would thus also include the study of lobbying and lobbyists as a topic in its own right, drawing on insights from economics and political science, such as that showing the value to lobbyists, measured by their income, of previous service on the staff of a politician (Vidal et al., 2012). Together, a better understanding of these often hidden areas may add to the emerging literature on why some countries seem able to implement effective policies while others do not (Mackenbach et al., 2013).

\section{References}

Adamini, S., E. Versluis and H. Maarse (2011), 'European policymaking on the tobacco advertising ban: the importance of escape routes', Health Economics, Policy and Law, 6(1): 65-84.

Alechnowicz, K. and S. Chapman (2004), 'The Philippine tobacco industry: "the strongest tobacco lobby in Asia"', Tobacco Control, 13(Supplement 2): ii71-ii78.

Bachinger, E. and M. McKee (2007), 'Tobacco policies in Austria during the Third Reich', The International Journal of Tuberculosisand Lung Disease, 11(9): 1033-1037.

Bachinger, E., M. McKee, et al. (2008), 'Tobacco policies in Nazi Germany: not as simple as it seems', Public Health, 122(5): 497-505.

Bogdanovica, I., A. McNeill, et al. (2011), 'What factors influence smoking prevalence and smoke free policy enactment across the European Union Member States', PLoS One, 6(8): e23889.

Callard, C., H. Chitanondh, et al. (2001), 'Why trade and investment liberalisation may threaten effective tobacco control efforts', Tobacco Control, 10(1): 68-70.

Corlett, N. (2013), 'ALDE Priorities for the week of 23 Sept 2013'. Parliament Agenda, J. Baker, Brussels, viEUws.

Corporate Europe Observatory. (2014), 'Tobacco lobbyist to become European Commissioner? Exposing the power of corporate lobbying in the EU Brussels'. http://corporateeurope.org/ blog/tobacco-lobbyist-become-european-commissioner.

Costa, H., A. B. Gilmore, et al. (2014), 'Quantifying the influence of the tobacco industry on EU governance: automated content analysis of the EU Tobacco Products Directive', Tobacco Control, 23(6): 473-478. 
Gensini, G. F., M. H. Yacoub, et al. (2004), 'The concept of quarantine in history: from plague to SARS', Journal of Infection, 49(4): 257-261.

Glenny, M. (2009), McMafia: Seriously Organised Crime, London: Random House.

Gruning, T., A. B. Gilmore, et al. (2006), 'Tobacco industry influence on science and scientists in Germany', American Journal of Public Health, 96(1): 20-32.

Hager, N. (2014), Dirty Politics, Nelson: Craig Potton Publishing.

Jarman, H. (2014), 'Public health and the Transatlantic Trade and Investment Partnership', European Journal of Public Health, 24(2): 181.

Mackenbach, J. P., M. Karanikolos, et al. (2013), 'The unequal health of Europeans: successes and failures of policies', Lancet, 381(9872): 1125-1134.

Mandal, S., A. Gilmore, et al. (2009), Block, amend, delay: tobacco industry efforts to influence the European Union's Tobacco Products Directive (2001/37/EC), Brussels: Smoke Free Partnership.

McKee, M. (2006), ‘A European alcohol strategy', BMJ, 333(7574): 871-872.

McKee, M. (2009), 'Opium, tobacco and alcohol: the evolving legitimacy of international action', Clinical Medicine, 9(4): 338-341.

McKee, M. (2014), 'Social media attacks on public health advocates', BMJ, 349: g6006.

McKee, M. E., E. E. Mossialos, et al. (2002), The Impact of EU Law on Health Care Systems, Brussels: P.I.E.-Peter Lang.

Neuman, M., A. Bitton, et al. (2002), 'Tobacco industry strategies for influencing European Community tobacco advertising legislation', The Lancet, 359(9314): 1323-1330.

Ozieranski, P., M. McKee, et al. (2012), 'Pharmaceutical lobbying under postcommunism: universal or country-specific methods of securing state drug reimbursement in Poland?', Health Economics, Policy and Law, 7(2): 175-195.

Peeters, S., H. Costa, et al. (2015), 'The Revision of the 2014 European tobacco products directive: an analysis of the tobacco industry's attempts to "break the health silo", Tobacco Control, doi:10.1136/tobaccocontrol-2014-051919.

Philip Morris International. (2013), 'Copy of new Transparency Register. Lists of consultants and their expenses'. From internal Philip Morris International documents leaked in September 2013.

Proctor, R. N. (2008), 'On playing the Nazi card', Tobacco Control, 17(5): 289-290.

Reynolds, L. and M. McKee (2010), 'Organised crime and the efforts to combat it: a concern for public health', Global Health, 6: 21.

Scharpf, F. W. (1997), Games Real Actors Play: Actor-Centered Institutionalism in Policy Research, Boulder, CO: WestviewPress.

Skafida, V., K. E. Silver, et al. (2014), 'Change in tobacco excise policy in Bulgaria: the role of tobacco industry lobbying and smuggling', Tobacco Control, 23(e1): e75-e84.

Stuckler, D., M. McKee, et al. (2012), 'Manufacturing epidemics: the role of global producers in increased consumption of unhealthy commodities including processed foods, alcohol, and tobacco', PLoS Medicine, 9(6): e1001235.

Titeca, K., L. Joossens, et al. (2011), 'Blood cigarettes: cigarette smuggling and war economies in Central and Eastern Africa', Tobacco Control, 20(3): 226-232.

Tridimas, T. (2006), The General Principles of EU Law, Oxford: Oxford University Press.

Vidal, J. B. I., M. Draca, et al. (2012), 'Revolving door lobbyists', The American Economic Review, 102(7): 3731-3748.

World Health Organization. (2009), The Global Tobacco Crisis, Geneva: World Health Organization. 